\title{
Eliminating schistosomes through vaccination: what are the best immune weapons?
}

\author{
Cristina Toscano Fonseca $^{1,2}{ }^{*}$, Sergio Costa Oliveira ${ }^{2,3}$ and Clarice Carvalho Alves ${ }^{1}$ \\ 1 Laboratório de Esquistossomose do Centro de Pesquisas René Rachou, Fundação Oswaldo Cruz, Belo Horizonte, Brazil \\ 2 Instituto Nacional de Ciência e Tecnologia em Doenças Tropicais (INCT-DT), Conselho Nacional de Desenvolvimento Científico e Tecnológico, Ministério de Ciência \\ Tecnologia e Inovação, Universidade Federal de Minas Gerais, Belo Horizonte, Brazil \\ ${ }^{3}$ Departamento de Bioquímica e Imunologia do Instituto de Ciências Biológicas, Universidade Federal de Minas Gerais, Belo Horizonte, Brazil
}

\section{Edited by:}

Ahmad Ali Othman, Tanta Faculty of

Medicine, Egypt

Reviewed by:

Peter Timmerman, Pepscan

Therapeutics B.V., Netherlands

Afzal A. Siddiqui, Texas Tech University

Health Sciences Center, USA

${ }^{*}$ Correspondence:

Cristina Toscano Fonseca, Laboratório

de Esquistossomose do Centro de

Pesquisas René Rachou, Fundação

Oswaldo Cruz, Av. Augusto de Lima

1715 Sala 212, Belo Horizonte, Minas

Gerais 30190-002, Brazil

e-mail: ctoscano@cpqrr.fiocruz.br
The successful development of vaccines depends on the knowledge of the immunological mechanisms associated with the elimination of the pathogen. In the case of schistosomes, its complex life cycle and the mechanisms developed to evade host immune system, turns the development of a vaccine against the disease into a very difficult task. Identifying the immunological effector mechanisms involved in parasite attrition and the major targets for its response is a key step to formulate an effective vaccine. Recent studies have described some promising antigens to compose a subunit vaccine and have pointed to some immune factors that play a role in parasite elimination. Here, we review the immune components and effector mechanisms associated with the protective immunity induced by those vaccine candidates and the lessons we have learned from the studies of the acquired resistance to infection in humans. We will also discuss the immune factors that correlate with protection and therefore could help to evaluate those vaccine formulations in clinical trials.

Keywords: schistosome vaccine, protective immunity, schistosomiasis, effector mechanisms, immune response

\section{INTRODUCTION}

Vaccination is a great strategy to control and eradicate diseases (1) and there is no doubt that the development of a vaccine against schistosomiasis would have a massive impact on disease control and would be useful as a complementary tool to the disease eradication (2). Schistosomes in contrast to viruses and bacteria are complex parasites that pass through different life stages in different anatomic sites of its definitive host (3). The parasite has evolved to live for decades in the host, developing interesting strategies to evade host immune system [reviewed in Ref. (4)]. So developing an effective vaccine against schistosomes is a difficult task. But since the parasite does not replicate in its definitive host, even a partial reduction in parasite burden is believed to have an impact on disease control and eradication.

For decades, scientists have tried to develop an effective vaccine formulation against schistosomes, and although two candidates are under clinical trials, the search for new candidates and vaccine formulations are far from ending. During all those years of studies on schistosome vaccine development, some immunological mechanisms involved in parasite elimination have been proposed. Complement activation has been suggested to be involved in parasite elimination, but from what we know so far, only recently transformed schistosomes are killed by complement and $24 \mathrm{~h}$ schistosomula became refractory to death induced by complement activation (5). Since most of these studies on complement activation and parasite death were performed in vitro, the significance of complement activation to parasite death in vivo can be questioned. Schistosomes only get to host vessels $72 \mathrm{~h}$ after penetrating the host and by this time the parasite is already resistant to death induced by complement (6). Indeed, many evasion mechanisms developed by the parasite have been described and give support to the idea that the activation of the membrane attack complex might not be the major mechanism involved in parasite elimination (7-10).

Antibody-dependent cellular cytotoxicity (ADCC) is another immune mechanism that has been associated with parasite elimination. In individuals living in endemic areas for schistosomiasis, ADCC involving IgE, IgG, eosinophils, monocytes, and platelets was associated with the acquisition of resistance to reinfection (11-13). In mice, ADCC has been highlighted as the immune mechanism involved in parasite death in animals immunized with Smp-80 and GST (14-16). However, eosinophils may not be the major cell involved in ADCC in mice, since deficiency in this cell did not result in any changes in worm and egg burden after infection, demonstrating that eosinophils do not play major roles in parasite death (17).

Regardless of the mechanisms involved, antibodies are key players in the protective immunity induced by vaccines. Immunization of mice deficient in B cells impaired the protective response induced in wild-type animals by vaccination with irradiated cercariae (18). Also, transference of sera from mice immunized with schistosomula tegument (Smteg) or Smp-80 to a naïve recipient induce partial protection against challenge infection $(19,20)$. Other evidence of the importance of antibodies in the protective immune response induced by vaccination comes from the studies of Hewiston and coworkers (21). They demonstrated that the protective immune response induced by attenuated cercariae was abrogated in CD154-deficient mice. CD40-CD154 interaction is involved in eliciting a humoral immune response dependent on 
T cells (22). The inoculation of IL-12 together with the vaccine in these deficient mice restored all the cellular immune parameters in mice lung but failed to restore protection and antibody production (21).

Cellular immune responses are also important in parasite elimination. Immunization of C57BL- 6 mice deficient on IFN- $\gamma$, and TNFRI impair or abrogate protection induced by vaccine $(18,23$, 24). The role of IFN- $\gamma$ and TNF- $\alpha$ in parasite killing seems to be related to nitric oxide production by macrophage. Immunization of mice deficient in the TNFRI with irradiated cercariae abrogates protection and impairs nitric oxide synthase (iNOS) expression in lung macrophages (24). Nevertheless, immunization of mice deficient in iNOS result only in partial reduction on the protective immunity induced by irradiated cercariae, indicating that nitric oxide is not the major factor involved in parasite death (25).

In BALC-c mice, deficiency in IL-4R expression abrogates protection induced by irradiated cercariae that can be restored by wild-type serum transference (26). Recently, protective immunityassociated Th2 profile was observed in outbred mice immunized with glyceraldehyde 3-phosphate dehydrogenase (SG3PDH) and peroxiredoxin (TPX) (27). IL-10 and IL-17 production seems to correlate negatively with protection. Blocking IL-10 with neutralizing antibodies enables protection against challenge infection in mice previously infected with Schistosoma mansoni and treated with praziquantel (28). In S. japonicum infection, blocking IL-17 with neutralizing antibodies enhances antibody production and protection in infected mice (29).

Although CD8+ cells are classically related to immune responses against intracellular pathogens, its role in schistosome elimination has been recently described (30). Immunization of mice with the S. japonicum 22.6/26GST coupled to Sepharose 4B bead induced a significant reduction in parasite burden that was associated with an increase in the number of activated CD8+ cells (30). These activated CD8 + cells were able to promote death of parasite carrying host MHCI molecules in its surface (30).

Coulson and Wilson (31) suggested that the major mechanism involved in parasite elimination after immunization with the irradiated cercariae vaccine was in fact the generation of an inflammatory focus in the lung of immunized mice that impairs parasite migration and therefore its transformation into adult worms (31). Evidence that support this hypothesis is given by histological examination of mouse's lungs which demonstrates that the parasites in the inflammatory foci were alive and when recovered from the lung and transferred to a naïve recipient they developed into adult worms $(31,32)$.

Besides all the knowledge generated and described so far, the majority of the studies on immune mechanisms involved in schistosome elimination have been performed using the irradiated cercariae strategy that for security reason are not used in human trials. Currently, researchers are developing vaccine formulations based on one or a cocktail of parasite antigens and although there are many studies on different vaccine strategies, little is known about the effective protective mechanisms. In this review, the immune components and mechanisms elicited by different vaccine strategies using subunit formulations containing promising parasite antigens will be described. We will evaluate whether there is (are) immune factor(s) that correlates with protection. And this information might be used to rationally design a vaccine formulation and to suggest a strategy that better elicits these protective responses. These correlates of protection can also help to evaluate whether those vaccines are effective during clinical trials.

\section{THE IMMUNE RESPONSE ELICITED BY PROMISING SCHISTOSOME ANTIGENS}

Some of the schistosome antigens tested in pre-clinical trials emerged as promising candidates to compose an antischistosomiasis vaccine due to their ability to consistently induce protective immune responses in different animal models, under different formulations and vaccine strategies.

Two schistosome antigens are under clinical trials, the fatty acid-binding protein of $14 \mathrm{kDa}$ from S. mansoni, Sm14 (33), and the glutathione- $S$-transferase of $28 \mathrm{kDa}$ from S. haematobium (34). The S. mansoni tetraspanin 2, TSP-2, is now been produced under good manufacture practices (GMP) to soon be evaluated in Phase I clinical Trial (35).

\section{GLUTATHIONE $\boldsymbol{S}$-TRANSFERASE}

The $28 \mathrm{kDa}$ glutathione $S$-transferase of S. mansoni, Sm28GST, is one of the most promising vaccine candidates. Recognized as the enzyme glutathione $S$-transferase (36), Sm28GST was identified in tegument, parenchyma, and genital organs of schistosomula and adult worm $(16,37)$. In the vaccine protocol, Sm28GST purified protein was able to significantly reduce the worm burden in rats and mice (16). In vitro experiments suggested that this protection was related to the cytotoxic response since in the presence of antiSm28GST antibodies and mouse eosinophils, schistosomula can be killed through ADCC $(15,16)$. The importance of antibodies in worm elimination was evaluated by the passive transfer of specific antibodies which were able to induce protection against challenge infection (16). A study performed by Boulanger and colleagues (38) reinforced the immunoprotective potential of Sm28GST protein, by demonstrating that immunization of baboons with the recombinant protein together with aluminum hydroxide (Alum) confers up to $80 \%$ of protection.

Several studies demonstrated the importance of antibodies in parasite elimination in animals immunized with Sm28GST. Mouse immunization with one dose of rSm28GST plus bacillus CalmetteGuérin (BCG) or Alum, as adjuvants, conferred protection against $S$. mansoni infection, and induced significant production of specific IgG, IgA, and IgE (39). In another study, mice immunization with Sm28GST produced in recombinant Mycobacterium bovis $\mathrm{BCG}$, regardless of the immunization route induced a vigorous production of IgG1, IgG2a, and IgG2b levels, which was associated with the neutralization of the Sm28GST enzymatic activity (40). Intradermal immunization with a DNA encoding Sm28GST, also induced a significant production of anti-Sm28GST IgG antibodies, mainly IgG2a and IgG2b, with an ability to kill schistosomula through ADCC mechanism (41). In addition to the antibodies, the cellular immunity is also critical to Schistosoma elimination. Mice immunized with the recombinant Sm28GST protein or with peptide derived from C-terminal region showed reduction in worm burden, in fibrosis, and in the number of eggs in the liver that were associated with high levels of IFN- $\gamma(42,43)$. In a DNA vaccine strategy, immunization of mice with Sm28GST co-delivered with 
an IL-18-encoding plasmid, also induced a strong IFN- $\gamma$ production and result in a significant reduction in egg and worm burden, reinforcing the importance of the Th1 response to the protection induced by Sm28GST (44).

One important feature of Sm28GST is the existence of crossreactivity with other Schistosoma species, including S. haematobium, S. japonicum, and S. bovis (45). This property can be explored in the context of vaccine development which can act to eliminate different Schistosoma species at the same time. In this sense, it was demonstrated that immunization of primates with rSm28GST protect against heterologous infection with $S$. haematobium (46). The Sh28GST (GST protein derived from $S$. haematobium) has the ability to confer protection in monkeys that showed a reduction in worm fecundity (47). The results of the studies with schistosome GST as antigen in vaccine formulations clearly demonstrate the importance of antibodies for anti-fecundity effect and parasite elimination, through neutralization and ADCC mechanisms, respectively. It is important to note that this antigen can induce protection by reducing worm burden or female fecundity and thus this vaccine formulation is efficient to limit infection and pathology.

\section{Sm14}

Sm14 is a $S$. mansoni fatty acid-binding protein that might be involved in lipid uptake from the host (48). Due to its predicted function, Sm14 represent an interesting target for vaccines against schistosomes. Schistosomes are unable to synthesize fatty acids and sterols through de novo pathway and therefore require host lipids to maintain its complex membrane system and physiological function $(49,50)$. Sm14 is expressed in the cercariae, schistosomula, adult worm, and eggs and located in the parasite tegument and gut, both tissue that represent the interface between parasite and host (51).

The ability of rSm14 to protect against schistosomiasis was first demonstrated by Tendler and coworkers (52). In their study, immunization of mice with $\mathrm{rSm} 14$ alone or formulated with Freund's adjuvant (FA) induced protection levels ranging from 50 to $68 \%$ (52). In rabbits, $\mathrm{rSm} 14$ plus FA elicited $89 \%$ protection against challenge infection (52). Interestingly, Sm14 was also able to protect mice from Fasciola hepatica infection thus demonstrating its potential to be used in a vaccine formulation against both parasites (52).

In the case of Sm14, the protective immune response is dependent on IFN- $\gamma$ and TNF- $\alpha$ production since in mice deficient in those cytokines, immunization with the recombinant form of Sm14 fails to induce protection (23). The importance of cellular components in the protective immune response elicited by Sm14 is also shown by the ability of epitopes from Sm14 to induce proliferative response in lymphocytes from resistant individuals and to induce protection in mice $(53,54)$. Immunization of mice with $S m 14$ gene also induced significant protection associated with antibody production and increased production of IFN- $\gamma$ by spleen cells and lung lavage cells (55). In a DNA vaccine strategy, the use of $I L-12$ as adjuvant induced a significant production of IL-10 and nitric oxide and failed to induce antibody production and protection (55). The role of antibodies in the protective immunity induced by Sm14 cannot be ruled out. Although so far no direct role for antibodies in parasite elimination have been described, all the successful vaccine formulation containing Sm14 induce significant antibody production $(23,54,55)$. Therefore, the role of antibodies in the protective immunity induced by Sm14 is a key question that has to be addressed if they are to be used as correlates of protection in future clinical trials.

\section{TETRASPANINS}

Tetraspanins are members of membrane-spanning proteins containing four transmembrane domains, three short intracellular domains, and two extracellular loops (EC1 and EC2) (56). In schistosomes, tetraspanins are located in the outer tegument, thus in contact with host immune system (57). The EC2 loop mediates protein-protein interactions (58) that are important to tetraspanin role in the molecular organization of cell membranes. Through interaction with many proteins, tetraspanins form a complex termed as tetraspanin-enriched microdomains (TEM) (59). The importance of tetraspanins to parasite survival was recently demonstrated using interference RNA technique (RNAi). Silencing $T s p-1$ and $T s p-2$ transcription resulted in significant reduction in the number of worm that reaches maturity in the mammalian host. Also, schistosomula treated with Sm Tsp-2 double strand RNA displayed vacuolated and thinner tegument, demonstrating TSP-2 role in maintaining tegument integrity (60).

Immunization of mice with a recombinant form of TSP-1 and TSP-2 resulted in $29-38$ or $53-61 \%$ reduction in worm burden, respectively. The protection was associated with an increased titer for IgG1 and IgG2a antibody (61). Immunization of mice with a vaccine formulation containing TSP-2, Alum, and CpG as adjuvant elicited a protection level ranging from 25 to $27 \%$. In this vaccine formulation, although significant titers of IgG antibodies were observed, there was no clear association between antibody levels and parasite burden and also there was no significant increased production of cytokine specific for TSP-2 immunized group. In contrast, an increased level of IFN- $\gamma$, IL-4, and IL-10 were observed in mice immunized with a chimerical protein containing TSP-2 and the 5B region of the hookworm aspartic protease Na-APR-1 (62). Besides the great result observed against S. mansoni infection, TSP-2 orthologs in S. japonicum do not represent a good vaccine candidate, since in this species TSP-2 is extremely polymorphic (63).

\section{Smp-80}

Another promising antigen is the large subunit of calpain, Smp80. Schistosome calpain is composed of a smaller subunit of $28 \mathrm{kDa}$ and a larger subunit of $78 \mathrm{kDa}(64)$. The large subunit was described to be localized in the parasite surface (64). This subunit has proteolytic activity in the presence of $\mathrm{Ca} 2+(64)$ and plays an important role in immune evasion. Smp-80 is involved in the renewal/recycling of the parasite surface, an important evasion mechanism used by the parasite to escape from host immune system (65).

The large subunit of calpain has been evaluated in different vaccine formulations and strategies and the immune components produced in response to immunization have also been described. This antigen induced significant protection in mice, baboon, and hamster and protects against S. mansoni, S. japonicum, and 
S. haematobium (66-68). Immunization of mice with naked DNA containing Smp-80 gene resulted in 39\% of reduction in worm burden, the use of $I L-2$ and $I L-12$ gene as adjuvant increased the protection level to 57 and $45 \%$, respectively. This increased protection was associated with an increased production of specific IgG2a and IgG2b, increased proliferative response, and IFN- $\gamma$ production $(69,70)$. The use of GM-CSF and $I L-4$ gene as adjuvant resulted in 42 and $44 \%$ reduction in worm burden associated with increased production of IL-4, IgG, IgG1, and IgG2b in GM-CSF immunized animals and IL-4 and IgG3 in $I L-4$ immunized group $(70,71)$. When the recombinant form of Smp-80 is used as antigen either in its recombinant form or in a prime-boost regimen, higher titers of antibodies and significant production of IL- 2 and IFN- $\gamma$ are observed and this immune profile is associated with a reduction of 51 and $49 \%$ in worm burden (66). Therefore, the protective immune response induced by Smp- 80 seems to correlate to a Th1 profile with increased IFN- $\gamma$ and antibody production especially IgG2a.

Indeed in mice immunized with Smp-80, antibodies play an important role in the elimination of the parasite. Transference of sera from $5 m p$ - 80 immunized mice to a naïve recipient result in $31-45 \%$ reduction in worm burden after a challenge infection (20). Complement seems not to play a major role in the parasite elimination once immunization of mice deficient in C3 factor with Smp-80 did not result in significant reduction of the protection level observed in wild-type mice (72). ADCC instead seems to be the immune mechanism involved in parasite death, increased number of dead schistosomula was observed in vitro when these parasites were incubated with sera from Smp-80 plus CpG immunized mice in the presence of lung lavage cells or lung cells (14). The increased percentage of dead parasites was associated with production of nitric oxide suggesting that the production of this molecule might be involved in ADCC-induced parasite killing (14).

\section{Sm29}

Sm29, other promising vaccine antigen, was identified by Cardoso and coworkers (73) using in silico analysis to identify in the S. mansoni transcriptome putative expressed proteins localized in the parasite tegument. The characterization of Sm29 demonstrated that this protein is expressed in the tegument of schistosomula and adult worm (74). The ability of Sm29 to induce protective immunity was assessed in mice with a vaccine formulation containing FA which resulted in a significant reduction of $51 \%$ in worm burden, $60 \%$ in intestinal eggs, and 50\% in liver granuloma area, associated with a significant production of IgG, IgG1and IgG2a-specific antibody, IFN- $\gamma$, TNF- $\alpha$, and IL-10 cytokine production (74).

\section{IMMUNE RESPONSE INDUCED BY MULTIVALENT FORMULATIONS}

Schistosomes are complex parasites and thus the design of a multivalent vaccine against the parasite might enhance subunit vaccine efficacy. Recently, these multivalent vaccine formulations containing promising antigens have been tested. Sm29 was tested together with the SmTSP-2 in a multivalent chimeric recombinant vaccine in mice, aiming to enhance the single antigen vaccination efficacy. The vaccine formulation with a chimeric protein containing TSP-2 and the C-terminal part of Sm29 resulted in a small increase in the protection level induced by $\mathrm{rSm} 29$ alone from 20.36 to $34.83 \%$ (75), or by rTSP-2 alone from 27 to $34.83 \%(62,75)$ when formulated with CpG-ODN plus alum. The chimeric protein induced a significant production of IgG and IgG2a-specific antibodies and a Th1 immune profile (75).

Another chimeric formulation combining Sm29 and Sm14 recombinant proteins was tested in vaccine protocol associated or not with poly (I:C)-adjuvant. Although immunization of Swiss mice with a subunit vaccine containing $\mathrm{rSm} 14$ or rSm29 alone did not induce significant reduction in adult worm, the vaccine formulation containing both $\mathrm{rSm} 14$ and $\mathrm{rSm} 29$ elicited 31 or $40 \%$ protection when it was formulated without adjuvant or with Poly (I:C), respectively (76).

The results observed in these multivalent formulations demonstrate that it is a promising strategy, but the choice of antigens that induce similar protective immune profile is a key step for the success of the vaccine formulation.

\section{WHAT CAN WE LEARN FROM THE STUDIES IN HUMANS?}

In endemic areas, the existence of naturally resistant individuals (77) that present persistently negative stool examination even if they are in constant contact with contaminated water enable the search for immune factors and biomarkers involved in resistance to Schistosoma infection.

Studies on human immune responses to Sm14, demonstrate that CD4+ T cells from naturally resistant individuals mounted a Th1-type of immune response to $\mathrm{rSm} 14$, based on IFN- $\gamma$ and TNF- $\alpha$ production (78). Moreover, T-cell proliferative responses to $\mathrm{rSm} 14$ from these individuals were totally abrogated after treatment with anti-IFN- $\gamma$ antibodies. These individuals also produce significant levels of IgG1 and IgG3 antibodies against Sm14, subclasses associated with parasite killing (79). Significant production of IgG1 and IgG3 specific for Sm29 and TSP-2 were also observed in individuals naturally resistant to $S$. mansoni infection $(61,80)$.

Human antibody responses to the large subunit of schistosomal calpain have also been associated with resistance. In humans infected with S. japonicum-presenting light infections, a strong reactivity to calpain was observed whereas in individuals with stronger infection, low reactivity to calpain was observed (81). In a study in an endemic area for schistosomiasis in Egypt, IFN- $\gamma$ production in response to Sm14 and IgE and IgA antibodies against Sm28GST correlated with resistance to infection (82).

Grzych and colleagues (83) reinforce the pivotal role of the antibodies in protection. They show that IgA specific to Sm28GST were present in the sera from infected individuals before and after treatment with praziquantel and that these immunoglobulins have a key role in neutralizing the GST enzyme activity which resulted in impaired female fecundity.

Since 1998, Sh28GST recombinant protein plus aluminum hydroxide adjuvant has been tested in the human population. Partial results of the phase I clinical trials were published by Riveau and colleagues (34), in their study, no relevant side effects or toxicity following vaccine administration was observed. Humoral immune responses generated by the vaccine were characterized by high levels of IgG1 and IgG3 production and low levels of IgG2 and IgA. The cellular response profile was characterized 
Table 1 | Summary of the protection levels and immune components elicited by immunization.

\begin{tabular}{|c|c|c|c|c|c|c|}
\hline Antigen & $\begin{array}{l}\text { Immunization } \\
\text { strategy }\end{array}$ & Adjuvant & $\begin{array}{l}\text { Protection } \\
\text { level (\%) }\end{array}$ & Humoral response & Cellular response & Reference \\
\hline & DNA vaccine & None & 39 & & Prolif. IFN- $\gamma$, IL-4 & $(67-69)$ \\
\hline & & IL-2 & 57 & $\uparrow \lg G, \lg G 2 a$ and $b$ & $\uparrow$ Prolif. $\uparrow$ IFN- $\gamma \downarrow$ IL-4 & \\
\hline & & $\mathrm{IL}-12$ & 45 & $\uparrow \lg G, \lg G 2 a$ and $b$ & $\uparrow$ Prolif. $\uparrow$ IFN- $\gamma \downarrow$ IL-4 & \\
\hline & & IL-4 & 44 & $\uparrow \operatorname{lgG} 3$ & Prolif. IFN- $\gamma \uparrow I L-4$ & \\
\hline & & GM-CSF & 42 & $\uparrow \lg G, \lg G 1$ & Prolif. IFN- $\gamma \uparrow I L-4$ & \\
\hline \multirow[t]{8}{*}{ Smp-80 } & Prime $\mathrm{E}$ boost & Resiquimod & 49 & $\uparrow \lg G, \lg G 1, \lg G 2 a$ & $\mathrm{IL}-2$ and IFN- $\gamma$ & $(70)$ \\
\hline & & (R848) & & and $b, \lg G 3, \lg A, \lg M$ & & \\
\hline & Recombinant protein & Resiquimod & 51 & $\uparrow \lg G, \lg G 1, \lg G 2 \mathrm{a}$ & IL-2 and IFN- $\gamma$ & \\
\hline & & (R848) & & and $b, \lg G 3, \lg A, \lg M$ & & \\
\hline & & CpG-ODN & 52.86 & $\lg G, \lg G 1, \lg G 2 b$ & ADCC AND NO production & $(14,71)$ \\
\hline & & & & $\lg G 3, \lg M$ & & \\
\hline & Recombinant protein & None & 25 & & & $(22)$ \\
\hline & & FA & 25 & $\uparrow \lg G 2 \mathrm{a}$ & & \\
\hline \multirow[t]{4}{*}{ Sm14 } & & rIL-12 & 42.2 & $\uparrow \lg G 2 a$ & Protection is dependent on & \\
\hline & & & & & IFN- $\gamma$ and TNF- $\alpha$ production & \\
\hline & DNA vaccine & None & 40.5 & $\lg G$ & IFN- $\gamma$ by SC and BAL cells & $(53)$ \\
\hline & Synthetic peptides & FA + Padre & $26-36.7$ & $\lg G 1, \lg G 2 a$ & $|F N-\gamma| L-10$ & $(52)$ \\
\hline \multirow[t]{2}{*}{ Sm29 } & Recombinant protein & FA & 51 & $\lg G 1, \lg G 2 a$ & IFN- $\gamma$, TNF- $\alpha$, IL-10 & $(73)$ \\
\hline & & CpG-Alum & 20 & $\lg G, \operatorname{lgG} 1, \lg G 2 a$ & IFN- $\gamma$ & $(74)$ \\
\hline TSP-1 & Recombinant protein & FA & $29-38$ & $\operatorname{lgG} 1, \lg G 2 a$ & Not reported & (59) \\
\hline \multirow[t]{3}{*}{ TSP-2 } & Recombinant protein & FA & $53-61$ & $\lg G 1, \lg G 2 a$ & Not reported & (59) \\
\hline & & Alum + CpG & $25-27$ & $\lg G, \operatorname{lgG} 1^{a}$ & IL-4, IFN- $\gamma$, and IL-10 & $(60)$ \\
\hline & Purified protein & FA & $40-68.3$ & Not reported & Eosinophils (ADCC) & $(16)$ \\
\hline \multirow[t]{2}{*}{ Sm28GST } & Recombinant protein & Alum & 46 & Not significant & IL-2 and IFN- $\gamma$ & $(41)$ \\
\hline & DNA vaccine & IL-18 & 23 & Not significant & IFN- $\gamma$ & $(42)$ \\
\hline \multirow[t]{2}{*}{ Sh28GST } & Recombinant protein & FA & 77 (fecundity) & $\lg G$ and $\lg A$ & Not reported & $(45)$ \\
\hline & & $\mathrm{BCG}$ & 60 & $\lg G$ & & \\
\hline
\end{tabular}

${ }^{a}$ No association with protection;

${ }^{b}$ production in response to infection and not to immunization; SC, spleen cells; BAL, broncho alveolar lavage; $\uparrow$ compared to vaccine formulation without adjuvant.

by significant production of IL-5 and IL-13, resulting in a Th2 predominant response. The ability of antibodies to inhibit the enzymatic Sh28GST activity was also observed, corroborating with experimental studies (34).

\section{CONCLUSION AND FUTURE PERSPECTIVE}

Understanding the immunological mechanisms involved in parasite elimination during an infection is a key step toward the development of an effective vaccine. Here, we reviewed the immune components activated under different formulations containing antigens described as promising candidates to compose an antischistosomiasis vaccine (summarized in Table 1). Although for some of the antigens the immune mechanism involved in parasite death have been demonstrated, for others they are still to be identified. The biological role the target antigen plays in the survival of the parasite and the immunological components elicited by a protective formulation gives us an indication of what immune mechanisms might be involved in parasite death. Yet determining their involvement in protective immunity is still necessary. To address this question, the use of animals deficient in components of the immune system represents an interesting tool that should be further explored. Once those immune factors that correlate with protection are identified, they can be used as a biomarker of resistance in clinical trials.

\section{ACKNOWLEDGMENTS}

Authors acknowledge Dr. John Kusel for reviewing this manuscript. This work was supported by CNPq, INCT-DT/CNPq, Proep/CPqRR, FAPEMIG, and PapesVI/Fiocruz. Fellowship: C. C. Alves (Fapemig), C. T. Fonseca (PQ/CNPq), and S. C. Oliveira (PQ/CNPq).

\section{REFERENCES}

1. Andre FE, Booy R, Bock HL, Clemens J, Datta SK, John TJ, et al. Vaccination greatly reduces disease, disability, death and inequity worldwide. Bull World Health Organ (2008) 86:140-6. doi:10.2471/BLT.07.040089 
2. Oliveira SC, Fonseca CT, Cardoso FC, Farias LP, Leite LC. Recent advances in vaccine research against schistosomiasis in Brazil. Acta Trop (2008) 108:256-62. doi:10.1016/j.actatropica.2008.05.023

3. Gryseels B. Schistosomiasis. Infect Dis Clin North Am (2012) 26:383-97. doi:10.1016/j.idc.2012.03.004

4. Jenkins SJ, Hewitson JP, Jenkins GR, Mountford AP. Modulation of the host's immune response by schistosome larvae. Parasite Immunol (2005) 27:385-93. doi:10.1111/j.1365-3024.2005.00789.x

5. Novato-Silva E, Nogueira-Machado JA, Gazzinelli G. Schistosoma mansoni: comparison of the killing effect of granulocytes and complement with or without antibody on fresh and cultured schistosomula in vitro. Am J Trop Med Hyg (1980) 29:1263-7.

6. El Ridi R, Tallima H. Schistosoma mansoni ex vivo lung-stage larvae excretorysecretory antigens as vaccine candidates against schistosomiasis. Vaccine (2009) 27:666-73. doi:10.1016/j.vaccine.2008.11.039

7. Inal JM, Sim RB. A Schistosoma protein, Sh-TOR, is a novel inhibitor of complement which binds human C2. FEBS Lett (2000) 470:131-4. doi:10.1016/S00145793(00)01304-1

8. Pearce EJ, Hall BF, Sher A. Host-specific evasion of the alternative complement pathway by schistosomes correlates with the presence of a phospholipase C-sensitive surface molecule resembling human decay accelerating factor. J Immunol (1990) 144:2751-6.

9. Ramalho-Pinto FJ. Decay accelerating factor (DAF) as the host antigen with protective activity to complement killing of schistosomula. Mem Inst Oswaldo Cruz (1987) 82:213-6. doi:10.1590/S0074-02761987000800037

10. Marikovsky M, Arnon R, Fishelson Z. Proteases secreted by transforming schistosomula of Schistosoma mansoni promote resistance to killing by complement. J Immunol (1988) 141:273-8.

11. Butterworth AE, Sturrock RF, Houba V, Mahmoud AA, Sher A, Rees PH. Eosinophils as mediators of antibody-dependent damage to schistosomula. Nature (1975) 256:727-9. doi:10.1038/256727a0

12. Joseph M, Auriault C, Capron M, Ameisen JC, Pancré V, Torpier G, et al. IgEdependent platelet cytotoxicity against helminths. Adv Exp Med Biol (1985) 184:23-33. doi:10.1007/978-1-4684-8326-0_2

13. Khalife J, Dunne DW, Richardson BA, Mazza G, Thorne KJ, Capron A, et al. Functional role of human IgG subclasses in eosinophil-mediated killing of schistosomula of Schistosoma mansoni. J Immunol (1989) 142:4422-7.

14. Torben W, Ahmad G, Zhang W, Nash S, Le L, Karmakar S, et al. Role of antibody dependent cell mediated cytotoxicity (ADCC) in Sm-p80-mediated protection against Schistosoma mansoni. Vaccine (2012) 30:6753-8. doi:10.1016/j.vaccine. 2012.09.026

15. Balloul JM, Pierce RJ, Grzych JM, Capron A. In vitro synthesis of a 28 kilodalton antigen present on the surface of the schistosomulum of Schistosoma mansoni. Mol Biochem Parasitol (1985) 17:105-14. doi:10.1016/0166-6851(85)90131-8

16. Balloul JM, Grzych JM, Pierce RJ, Capron A. A purified 28,000 dalton protein from Schistosoma mansoni adult worms protects rats and mice against experimental schistosomiasis. J Immunol (1987) 138:3448-53.

17. Swartz JM, Dyer KD, Cheever AW, Ramalingam T, Pesnicak L, Domachowske JB, et al. Schistosoma mansoni infection in eosinophil lineage-ablated mice. Blood (2006) 108:2420-7. doi:10.1182/blood-2006-04-015933

18. Jankovic D, Wynn TA, Kullberg MC, Hieny S, Caspar P, James S, et al. Optimal vaccination against Schistosoma mansoni requires the induction of both

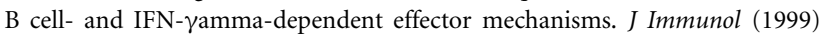
162:345-51

19. Melo TT, Sena IC, Araujo N, Fonseca CT. Antibodies are involved in the protective immunity induced in mice by Schistosoma mansoni schistosomula tegument (Smteg) immunization. Parasite Immunol (2014) 36:107-11. doi:10.1111/pim.12091

20. Torben W, Ahmad G, Zhang W, Siddiqui AA. Role of antibodies in Sm-p80mediated protection against Schistosoma mansoni challenge infection in murine and nonhuman primate models. Vaccine (2011) 29:2262-71. doi:10.1016/j. vaccine.2011.01.040

21. Hewitson JP, Hamblin PA, Mountford AP. In the absence of CD154, administration of interleukin-12 restores Th1 responses but not protective immunity to Schistosoma mansoni. Infect Immun (2007) 75:3539-47. doi:10.1128/IAI. 00252-07

22. Grewal IS, Flavell RA. CD40 and CD154 in cell-mediated immunity. Annu Rev Immunol (1998) 16:111-35. doi:10.1146/annurev.immunol.16.1.111
23. Fonseca CT, Brito CF, Alves JB, Oliveira SC. IL-12 enhances protective immunity in mice engendered by immunization with recombinant $14 \mathrm{kDa}$ Schistosoma mansoni fatty acid-binding protein through an IFN- $\gamma$ amma and TNF- $\alpha$ lpha dependent pathway. Vaccine (2004) 22:503-10. doi:10.1016/j. vaccine.2003.07.010

24. Street M, Coulson PS, Sadler C, Warnock LJ, McLaughlin D, Bluethmann H, et al. TNF is essential for the cell-mediated protective immunity induced by the radiation-attenuated schistosome vaccine. J Immunol (1999) 163:4489-94.

25. James SL, Cheever AW, Caspar P, Wynn TA. Inducible nitric oxide synthasedeficient mice develop enhanced type 1 cytokine-associated cellular and humoral immune responses after vaccination with attenuated Schistosoma mansoni cercariae but display partially reduced resistance. Infect Immun (1998) 66:3510-8.

26. Mountford AP, Hogg KG, Coulson PS, Brombacher F. Signaling via interleukin-4 receptor alpha chain is required for successful vaccination against schistosomiasis in BALB/c mice. Infect Immun (2001) 69:228-36. doi:10.1128/IAI.69.1.228236.2001

27. El Ridi R, Tallima H. Vaccine-induced protection against murine schistosomiasis mansoni with larval excretory-secretory antigens and papain or type-2 cytokines. J Parasitol (2013) 99:194-202. doi:10.1645/GE-3186.1

28. Wilson MS, Cheever AW, White SD, Thompson RW, Wynn TA. IL-10 blocks the development of resistance to re-infection with Schistosoma mansoni. PLoS Pathog (2011) 7:e1002171. doi:10.1371/journal.ppat.1002171

29. Wen X, He L, Chi Y, Zhou S, Hoellwarth J, Zhang C, et al. Dynamics of Th17 cells and their role in Schistosoma japonicum infection in C57BL/6 mice. PLoS Negl Trop Dis (2011) 5:e1399. doi:10.1371/journal.pntd.0001399

30. Zhou Y, Zhang H, Sun XJ, Zheng D, Liang YJ, Luo J, et al. Murine CD8(+)T cell cytotoxicity against schistosomula induced by inoculation of schistosomal 22.6/26GST coupled sepharose 4B beads. Vaccine (2012) 30:2440-7. doi:10.1016/j.vaccine.2012.01.068

31. Coulson PS, Wilson RA. Examination of the mechanisms of pulmonary phase resistance to Schistosoma mansoni in vaccinated mice. Am J Trop Med Hyg (1988) 38:529-39.

32. Coulson PS. The radiation-attenuated vaccine against schistosomes in animal models: paradigm for a human vaccine? Adv Parasitol (1997) 39:271-336. doi:10.1016/S0065-308X(08)60048-2

33. Oswaldo Cruz Foundation. Study to evaluate the safety of the vaccine prepared sm14 against schistosomiasis. ClinicalTrials.gov [Internet]. Bethesda (MD): National Library of Medicine (US) (2000). Available from: http://clinicaltrials. gov/ct2/show/study/NCT01154049

34. Riveau G, Deplanque D, Remoué F, Schacht AM, Vodougnon H, Capron M, et al. Safety and immunogenicity of rSh28GST antigen in humans: phase 1 randomized clinical study of a vaccine candidate against urinary schistosomiasis. PLoS Negl Trop Dis (2012) 6:e1704. doi:10.1371/journal.pntd.0001704

35. Curti E, Kwityn C, Zhan B, Gillespie P, Brelsford J, Deumic V, et al. Expression at a $20 \mathrm{~L}$ scale and purification of the extracellular domain of the Schistosoma mansoni TSP-2 recombinant protein: a vaccine candidate for human intestinal schistosomiasis. Hum Vaccin Immunother (2013) 9:2342-50. doi:10.4161/ hv.25787

36. Taylor JB, Vidal A, Torpier G, Meyer DJ, Roitsch C, Balloul JM, et al. The glutathione transferase activity and tissue distribution of a cloned $\mathrm{Mr} 28 \mathrm{~K}$ protective antigen of Schistosoma mansoni. EMBO J (1988) 7:465-72.

37. Liu JL, Fontaine J, Capron A, Grzych JM. Ultrastructural localization of Sm28 GST protective antigen in Schistosoma mansoni adult worms. Parasitology (1996) 113:377-91. doi:10.1017/S003118200006652X

38. Boulanger D, Reid GD, Sturrock RF, Wolowczuk I, Balloul JM, Grezel D, et al. Immunization of mice and baboons with the recombinant Sm28GST affects both worm viability and fecundity after experimental infection with Schistosoma mansoni. Parasite Immunol (1991) 13:473-90. doi:10.1111/j.1365-3024. 1991.tb00545.x

39. Grezel D, Capron M, Grzych JM, Fontaine J, Lecocq JP, Capron A. Protective immunity induced in rat schistosomiasis by a single dose of the Sm28GST recombinant antigen: effector mechanisms involving IgE and IgA antibodies. Eur J Immunol (1993) 23:454-60. doi:10.1002/eji.1830230223

40. Kremer L, Riveau G, Baulard A, Capron A, Locht C. Neutralizing antibody responses elicited in mice immunized with recombinant bacillus CalmetteGuérin producing the Schistosoma mansoni glutathione S-transferase. JImmunol (1996) 156:4309-17. 
41. Dupré L, Poulain-Godefroy O, Ban E, Ivanoff N, Mekranfar M, Schacht AM, et al. Intradermal immunization of rats with plasmid DNA encoding Schistosoma mansoni $28 \mathrm{kDa}$ glutathione S-transferase. Parasite Immunol (1997) 19:505-13. doi:10.1046/j.1365-3024.1997.d01-163.x

42. Pancré V, Wolowczuk I, Bossus M, Gras-Masse H, Guerret S, Delanoye A, et al. Evaluation of the effect of Sm28GST-derived peptides in murine hepatosplenic schistosomiasis: interest of the lipopeptidic form of the C-terminal peptide. $\mathrm{Mol}$ Immunol (1994) 31:1247-56. doi:10.1016/0161-5890(94)90075-2

43. Pancre V, Wolowczuk I, Guerret S, Copin MC, Delanoye A, Capron A, et al. Protective effect of rSm28GST-specific T cells in schistosomiasis: role of gamma interferon. Infect Immun (1994) 62:3723-30.

44. Dupré L, Kremer L, Wolowczuk I, Riveau G, Capron A, Locht C. Immunostimulatory effect of IL-18-encoding plasmid in DNA vaccination against murine Schistosoma mansoni infection. Vaccine (2001) 19:1373-80. doi:10.1016/S0264410X $(00) 00363-7$

45. Capron A, Dessaint JP, Capron M, Ouma JH, Butterworth AE. Immunity to schistosomes: progress toward vaccine. Science (1987) 238:1065-72. doi:10.1126/ science. 3317823

46. Boulanger D, Warter A, Trottein F, Mauny F, Brémond P, Audibert F, et al. Vaccination of patas monkeys experimentally infected with Schistosoma haematobium using a recombinant glutathione S-transferase cloned from S. mansoni. Parasite Immunol (1995) 17:361-9. doi:10.1111/j.1365-3024.1995.tb00903.x

47. Boulanger D, Warter A, Sellin B, Lindner V, Pierce RJ, Chippaux JP, et al. Vaccine potential of a recombinant glutathione S-transferase cloned from Schistosoma haematobium in primates experimentally infected with an homologous challenge. Vaccine (1999) 17:319-26. doi:10.1016/S0264-410X(98)00202-3

48. Moser D, Tendler M, Griffiths G, Klinkert MQ. A 14-kDa Schistosoma mansoni polypeptide is homologous to a gene family of fatty acid binding proteins. J Biol Chem (1991) 266:8447-54.

49. Furlong ST. Unique roles for lipids in Schistosoma mansoni. Parasitol Today (1991) 7:59-62. doi:10.1016/0169-4758(91)90192-Q

50. Meyer F, Meyer H, Bueding E. Lipid metabolism in the parasitic and free-living flatworms, Schistosoma mansoni and Dugesia dorotocephala. Biochim Biophys Acta (1970) 210:257-66. doi:10.1016/0005-2760(70)90170-0

51. Brito CF, Oliveira GC, Oliveira SC, Street M, Riengrojpitak S, Wilson RA, et al. Sm14 gene expression in different stages of the Schistosoma mansoni life cycle and immunolocalization of the Sm14 protein within the adult worm. Braz JMed Biol Res (2002) 35:377-81. doi:10.1590/S0100-879X2002000300014

52. Tendler M, Brito CA, Vilar MM, Serra-Freire N, Diogo CM, Almeida MS, et al. A Schistosoma mansoni fatty acid-binding protein, $\mathrm{Sml4}$, is the potential basis of a dual-purpose anti-helminth vaccine. Proc Natl Acad Sci U S A (1996) 93:269-73. doi:10.1073/pnas.93.1.269

53. Fonseca CT, Cunha-Neto E, Goldberg AC, Kalil J, de Jesus AR, Carvalho EM, et al. Human T cell epitope mapping of the Schistosoma mansoni $14-\mathrm{kDa}$ fatty acid-binding protein using cells from patients living in areas endemic for schistosomiasis. Microbes Infect (2005) 7:204-12. doi:10.1016/j.micinf.2004.10.012

54. Garcia TC, Fonseca CT, Pacifico LG, Durães Fdo V, Marinho FA, Penido ML, et al. Peptides containing $\mathrm{T}$ cell epitopes, derived from Sm14, but not from paramyosin, induce a Thl type of immune response, reduction in liver pathology and partial protection against Schistosoma mansoni infection in mice. Acta Trop (2008) 106:162-7. doi:10.1016/j.actatropica.2008.03.003

55. Fonseca CT, Pacífico LG, Barsante MM, Rassi T, Cassali GD, Oliveira SC. Coadministration of plasmid expressing IL-12 with $14-\mathrm{kDa}$ Schistosoma mansoni fatty acid-binding protein cDNA alters immune response profiles and fails to enhance protection induced by Sm14 DNA vaccine alone. Microbes Infect (2006) 8:2509-16. doi:10.1016/j.micinf.2006.06.008

56. Maecker HT, Todd SC, Levy S. The tetraspanin superfamily: molecular facilitators. FASEB J (1997) 11:428-42.

57. Braschi S, Curwen RS, Ashton PD, Verjovski-Almeida S, Wilson A. The tegument surface membranes of the human blood parasite Schistosoma mansoni: a proteomic analysis after differential extraction. Proteomics (2006) 6:1471-82. doi:10.1002/pmic.200500368

58. Hemler ME. Tetraspanin functions and associated microdomains. Nat Rev Mol Cell Biol (2005) 6:801-11. doi:10.1038/nrm1736

59. Hemler ME. Targeting of tetraspanin proteins-potential benefits and strategies. Nat Rev Drug Discov (2008) 7:747-58. doi:10.1038/nrd2659

60. Tran MH, Freitas TC, Cooper L, Gaze S, Gatton ML, Jones MK, et al. Suppression of mRNAs encoding tegument tetraspanins from Schistosoma mansoni results in impaired tegument turnover. PLoS Pathog (2010) 6:e1000840. doi:10.1371/ journal.ppat. 1000840

61. Tran MH, Pearson MS, Bethony JM, Smyth DJ, Jones MK, Duke M, et al. Tetraspanins on the surface of Schistosoma mansoni are protective antigens against schistosomiasis. Nat Med (2006) 12:835-40. doi:10.1038/nm1430

62. Pearson MS, Pickering DA, McSorley HJ, Bethony JM, Tribolet L, Dougall $\mathrm{AM}$, et al. Enhanced protective efficacy of a chimeric form of the schistosomiasis vaccine antigen Sm-TSP-2. PLoS Negl Trop Dis (2012) 6:e1564. doi:10.1371/journal.pntd.0001564

63. Cai P, Bu L, Wang J, Wang Z, Zhong X, Wang H. Molecular characterization of Schistosoma japonicum tegument protein tetraspanin-2: sequence variation and possible implications for immune evasion. Biochem Biophys Res Commun (2008) 372:197-202. doi:10.1016/j.bbrc.2008.05.042

64. Siddiqui AA, Zhou Y, Podesta RB, Karcz SR, Tognon CE, Strejan GH, et al. Characterization of $\mathrm{Ca}(2+)$-dependent neutral protease (calpain) from human blood flukes, Schistosoma mansoni. Biochim Biophys Acta (1993) 1181:37-44. doi:10.1016/0925-4439(93)90087-H

65. Silva EE, Clarke MW, Podesta RB. Characterization of a C3 receptor on the envelope of Schistosoma mansoni. J Immunol (1993) 151:7057-66.

66. Ahmad G, Zhang W, Torben W, Noor Z, Siddiqui AA. Protective effects of Sm-p80 in the presence of resiquimod as an adjuvant against challenge infection with Schistosoma mansoni in mice. Int J Infect Dis (2010) 14:e781-7. doi:10.1016/j.ijid.2010.02.2266

67. Zhang R, Yoshida A, Kumagai T, Kawaguchi H, Maruyama H, Suzuki T, et al. Vaccination with calpain induces a Th1-biased protective immune response against Schistosoma japonicum. Infect Immun (2001) 69:386-91. doi:10.1128/IAI.69.1. 386-391.2001

68. Siddiqui AA, Siddiqui BA, Ganley-Leal L. Schistosomiasis vaccines. Hum Vaccin (2011) 7:1192-7. doi:10.4161/hv.7.11.17017

69. Siddiqui AA, Phillips T, Charest H, Podesta RB, Quinlin ML, Pinkston JR, et al. Enhancement of Sm-p80 (large subunit of calpain) induced protective immunity against Schistosoma mansoni through co-delivery of interleukin-2 and interleukin-12 in a DNA vaccine formulation. Vaccine (2003) 21:2882-9. doi:10.1016/S0264-410X(03)00159-2

70. Siddiqui AA, Pinkston JR, Quinlin ML, Kavikondala V, Rewers-Felkins KA, Phillips T, et al. Characterization of protective immunity induced against Schistosoma mansoni via DNA priming with the large subunit of calpain (Sm-p80) in the presence of genetic adjuvants. Parasite (2005) 12:3-8. doi:10.1051/parasite/ 2005121003

71. Siddiqui AA, Phillips T, Charest H, Podesta RB, Quinlin ML, Pinkston JR, et al. Induction of protective immunity against Schistosoma mansoni via DNA priming and boosting with the large subunit of calpain (Sm-p80): adjuvant effects of granulocyte-macrophage colony-stimulating factor and interleukin-4. Infect Immun (2003) 71:3844-51. doi:10.1128/IAI.71.7.3844-3851.2003

72. Karmakar S, Zhang W, Ahmad G, Alam MU, Winn R, Torben W, et al. Complement plays a minimal role in Sm-p80-mediated protection against Schistosoma mansoni. Hum Vaccin Immunother (2014) 10:640-7. doi:10.4161/ hv. 27576

73. Cardoso FC, Pinho JM, Azevedo V, Oliveira SC. Identification of a new Schistosoma mansoni membrane-bound protein through bioinformatic analysis. Genet Mol Res (2006) 5:609-18.

74. Cardoso FC, Macedo GC, Gava E, Kitten GT, Mati VL, de Melo AL, et al. Schistosoma mansoni tegument protein $\mathrm{Sm} 29$ is able to induce a Th1-type of immune response and protection against parasite infection. PLoS Negl Trop Dis (2008) 2:e308. doi:10.1371/journal.pntd.0000308

75. Pinheiro CS, Ribeiro AP, Cardoso FC, Martins VP, Figueiredo BC, Assis NR, et al. A multivalent chimeric vaccine composed of Schistosoma mansoni SmTSP-2 and Sm29 was able to induce protection against infection in mice. Parasite Immunol (2014) 36:303-12. doi:10.1111/pim.12118

76. Ewaisha RE, Bahey-El-Din M, Mossallam SF, Amer EI, Aboushleib HM, Khalil AM. Combination of the two schistosomal antigens Sm14 and Sm29 elicits significant protection against experimental Schistosoma mansoni infection. Exp Parasitol (2014) 145:51-60. doi:10.1016/j.exppara.2014.07.010

77. Correa-Oliveira R, Pearce EJ, Oliveira GC, Golgher DB, Katz N, Bahia LG, et al. The human immune response to defined immunogens of Schistosoma mansoni: elevated antibody levels to paramyosin in stool-negative individuals from two endemic areas in Brazil. Trans R Soc Trop Med Hyg (1989) 83:798-804. doi:10.1016/0035-9203(89)90334-9 
78. Brito CF, Caldas IR, Coura Filho P, Correa-Oliveira R, Oliveira SC. $\mathrm{CD} 4+\mathrm{T}$ cells of schistosomiasis naturally resistant individuals living in an endemic area produce interferon-gamma and tumour necrosis factor-alpha in response to the recombinant $14 \mathrm{KDA}$ Schistosoma mansoni fatty acid-binding protein. Scand J Immunol (2000) 51:595-601. doi:10.1046/j.1365-3083.2000. 00710.x

79. Brito CF, Fonseca CT, Goes AM, Azevedo V, Simpson AJ, Oliveira SC. Human IgG1 and IgG3 recognition of Schistosoma mansoni $14 \mathrm{kDa}$ fatty acid-binding recombinant protein. Parasite Immunol (2000) 22:41-8.

80. Cardoso FC, Pacífico RN, Mortara RA, Oliveira SC. Human antibody responses of patients living in endemic areas for schistosomiasis to the tegumental protein Sm29 identified through genomic studies. Clin Exp Immunol (2006) 144:382-91. doi:10.1111/j.1365-2249.2006.03081.x

81. Zhang R, Suzuki T, Takahashi S, Yoshida A, Kawaguchi H, Maruyama H, et al. Cloning and molecular characterization of calpain, a calcium-activated neutral proteinase, from different strains of Schistosoma japonicum. Parasitol Int (2000) 48:232-42. doi:10.1016/S1383-5769(99)00024-0

82. Al-Sherbiny M, Osman A, Barakat R, El Morshedy H, Bergquist R, Olds R. In vitro cellular and humoral responses to Schistosoma mansoni vaccine candidate antigens. Acta Trop (2003) 88:117-30. doi:10.1016/S0001-706X(03) 00195-5
83. Grzych JM, Grezel D, Xu CB, Neyrinck JL, Capron M, Ouma JH, et al. IgA antibodies to a protective antigen in human Schistosomiasis mansoni. J Immunol (1993) 150:527-35.

Conflict of Interest Statement: The authors declare that the research was conducted in the absence of any commercial or financial relationships that could be construed as a potential conflict of interest.

Received: 31 October 2014; accepted: 18 February 2015; published online: 09 March 2015.

Citation: Fonseca CT, Oliveira SC and Alves CC (2015) Eliminating schistosomes through vaccination: what are the best immune weapons? Front. Immunol. 6:95. doi: 10.3389/fimmu.2015.00095

This article was submitted to Immunotherapies and Vaccines, a section of the journal Frontiers in Immunology.

Copyright $\odot 2015$ Fonseca, Oliveira and Alves. This is an open-access article distributed under the terms of the Creative Commons Attribution License (CC BY). The use, distribution or reproduction in other forums is permitted, provided the original author(s) or licensor are credited and that the original publication in this journal is cited, in accordance with accepted academic practice. No use, distribution or reproduction is permitted which does not comply with these terms. 